\title{
Evaluation of bamboo as a feedstock for bioethanols in Taiwan
}

\author{
Ya-Nang Wang ${ }^{1,2}$, Chun-Han $\mathrm{Ko}^{2,3,{ }^{*}}$, Chih-Yuan Lee ${ }^{2}$, Heng-Ping Tsai ${ }^{2}$, Wen-Hua Chen ${ }^{4}$, \\ Wen-Song Hwang ${ }^{4}$, Ming-Jer Tsai ${ }^{1,2}$, Fang-Chih Chang ${ }^{5}$ \\ ${ }^{1}$ The Experimental Forest, National Taiwan University, Nan-Tou, Taiwan, R.O.C. \\ ${ }^{2}$ School of Forestry and Resource Conservation, National Taiwan University, Taipei, Taiwan, R.O.C. \\ ${ }^{3}$ Bioenergy Research Center, National Taiwan University, Taipei, Taiwan, R.O.C. \\ ${ }^{4}$ Cellulose Ethanol Program, Institute of Nuclear Energy Research, AEC, Taoyuan, Taiwan, R.O.C. \\ ${ }^{5}$ The Instrument Center, National Cheng Kung University, Tainan, Taiwan, R.O.C. \\ * Corresponding author. Tel: +886 2 33664615, Fax: +886 2 13211001,E-mail: chunhank@ntu.edu.tw
}

\begin{abstract}
The bamboo covers 152,300 ha in Taiwan, roughly of $7.2 \%$ the overall forest area. This study evaluated Ma bamboo (Dendrocalamus latiflorus Munro) as a feedstock for bioethanols in Taiwan. Acidic steam explosion was employed to prepare Ma bamboo chips, as well as alkaline steam explosion, bleached and unbleached kraft pulps. For the saccharification of pretreated bamboo biomaterials, cellulase formulations were applied with three dosages: 2, 6, 12 percents weights to dried pulps. For acidic exploded pulp, the optimal yields were $348.92 \pm 39.76 \mathrm{mg} / \mathrm{g}$ o. d. pulp, $68 \%$ of pulp alpha cellulose contents. The hydrolysis efficiencies were negatively impacted by lignin and xylan contents of pretreated bamboo biomaterials. Simultaneous saccharification and fermentation (SSF) were also conducted using Saccharomyces cerevisiae D5A under $38^{\circ} \mathrm{C}$ and $\mathrm{pH} 5$ at shake flask level. After 96 hours, $91.8 \mathrm{mg}$ ethanol per $\mathrm{g}$ of $\alpha$-cellulose was obtained for acid exploded pulp; $176.3 \mathrm{mg}$ ethanol per $\mathrm{g}$ of $\alpha$-cellulose was obtained for alkaline exploded pulp; $537.6 \mathrm{mg}$ ethanol per $\mathrm{g}$ of $\alpha$-cellulose was obtained for bleached bamboo pulp. Based on the experimental data, up to 10,700 tons of bioethanols could be produced annually by acidic steam explosion.
\end{abstract}

Keywords: Bamboo, Bioethanol, Simultaneous hydrolysis and fermentation, Steam explosion

\section{Introduction}

Bamboo stands cover 152,300 hecacres, roughly of $7.2 \%$ the overall forest area in Taiwan [1]. Bamboos are endemic in south and east Asia. Bamboo biomass is accumulating daily, but little of them has been used (edible bamboo shoots and inedible part as materials) and most of them are wasted without utilizing. Its accumulation is about 26.1 tons/ha, with annual growth around 13.84 tons/ha under 5 year rotation cutting. Its fast growth and adaptability toward various soil and climate conditions make the bamboo a good candidate for a renewable resource. Bamboo had been conventionally used as the raw materials for producing artefacts, utensils, plywood, fiberboard, and decorated multi-layered panels in Taiwan and many Asian countries. Recently, more attention was paid for bamboo biomass as biofuel feedstock, e. g., steam-exploded bamboo was employed for methane production [2].

Simultaneous saccharification and fermentation (SSF) processes were firstly described by Takagi et al. [3]: it combined enzymatic hydrolysis of cellulose and simultaneous fermentation of the fermentable sugars together to obtain ethanol. In the SSF process, the conditions are nearly the same as in separate hydrolysis and fermentation systems (SHF), just one different is that saccharification and fermentation are performed in the same reactor. Thus, put the yeast and the cellulolytic enzyme complex together reduces the accumulation and inhibition of sugars in the reactor which increasing ethanol yield and hydrolysis rate with respect to separate hydrolysis and fermentation [4]. Another advantage of SSF is that used one fermenter throughout the whole process reducing the facilities costs. This study evaluated Ma bamboo (Dendrocalamus latiflorus Munro) as a feedstock for bioethanols in Taiwan. Acidic and alkaline steam exploded bamboo biomass, as well as unbleached and bleached kraft bamboo pulps, were employed as raw materials to investigate the impact of lignin on SSF efficiencies. 


\section{Methodology}

\subsection{Materials}

The Ma Bamboo (Dendrocalamus latiflorus Munro) sample, approx. 4-year-old Ma Bamboo culms, was collected from the Experimental Forest of National Taiwan University. The stem was chopped into $6 \times 3 \mathrm{~cm}$ (length $\times$ width), then air dried for a mouth.

\subsection{Steam-explosion}

Air-dried bamboo sample was soaked into $1.5 \% \mathrm{H}_{2} \mathrm{SO}_{4}$ solution or $1.5 \% \mathrm{NaOH} \& \mathrm{Na}_{2} \mathrm{SO}_{3}$ solution for a week. Steam explosion conditions were: solid/liquid ratio=1:7; temperature and pressure of alkali-treated samples were held at 180,190 and $200^{\circ} \mathrm{C}$ from 10 to 20 minutes. Acid-treated sampled were held at $190^{\circ} \mathrm{C}$ for 10 minutes. Samples were then washed by tap water on 200 mesh screen until neutral, then kept in $4{ }^{\circ} \mathrm{C}$.

\subsection{Kraft pulping and bleaching}

Ma bamboo air-dried kraft pulp was cooked by $\mathrm{M} / \mathrm{K}$ digester with wood to liquid ratio $=1 / 4$ (w/v), $25 \%$ sulfidity and $17 \%$ active alkali. $\mathrm{H}$-factor is about 650 , with temperature raised at $1.5^{\circ} \mathrm{C} / \mathrm{min}$ to $160{ }^{\circ} \mathrm{C}$ in $90 \mathrm{~min}$, then kept at $160{ }^{\circ} \mathrm{C}$ for another $90 \mathrm{~min}$. After washing and screening, then keep in $4{ }^{\circ} \mathrm{C}$ refrigerator. Bleached pulps were prepared by a commercial DEDD bleaching sequence [5], and then washed and kept in $4{ }^{\circ} \mathrm{C}$ refrigerator. " $\mathrm{D}$ " and "E" stand for chlorine dioxide and alkali extraction stages.

\subsection{Enzyme hydrolysis}

Acid and alkali steam-exploded bamboo pulps (biomass) were hydrolyzed with cellulases complex 50010 and 50013 (containing xylanase) from Novozymes ${ }^{\circledR}$. Three enzyme loadings were equivalent to $1.5,4.5,9 \mathrm{IU}$ endoglucanase (CMCase) $/ \mathrm{mL}, 0.15,0.44,0.89$ IU cellobiohydrolases $/ \mathrm{mL}$, and 1.2, 2.4, 7.1 IU xylanase $/ \mathrm{mL}$ in reaction solutions. Hydrolysis was conducted in a total volume of $200 \mathrm{~mL}$ liquid with $0.05 \mathrm{M}$ citrate buffer $(\mathrm{pH} \mathrm{5),2.5 \%}$ $(\mathrm{w} / \mathrm{v})$ samples in a $250 \mathrm{~mL}$ conical flask. The flasks was water bathed at $50^{\circ} \mathrm{C}$, shaken at 100 rpm for $96 \mathrm{~h}$, and the samples were analyzed every $12 \mathrm{~h}$.

\subsection{Simultaneous saccharification and fermentation (SSF)}

$100 \mathrm{~mL}$ reaction solution, with 5\% (w/v) steam-exploded bamboo, $1 \%(\mathrm{w} / \mathrm{v})$ yeast extract and $2 \%(\mathrm{w} / \mathrm{v})$ peptone, was subject to $38^{\circ} \mathrm{C}$ and $\mathrm{pH} 5$ in a $250 \mathrm{~mL}$ conical flask. The sterilized reaction solution was inoculated with 5\% (v/v) Saccharomyces cerevisiae D5A culture solutions with optical density at 0.1 . The culture solution was prepared by was cultivated with yeast extract $10 \mathrm{~g} / \mathrm{L}$, peptone $20 \mathrm{~g} / \mathrm{L}$, dextrose $20 \mathrm{~g} / \mathrm{L}$ for $18 \mathrm{~h}$ at $100 \mathrm{rpm}$, $38^{\circ} \mathrm{C}$ on a rotary shaker. The enzymes were added into reaction solutions with endoglucanase $9 \mathrm{IU} / \mathrm{mL}$, cellobiohydrolases $0.89 \mathrm{IU} / \mathrm{mL}$ and xylanase $7 \mathrm{IU} / \mathrm{mL}$ at $38^{\circ} \mathrm{C}$ for $96 \mathrm{~h}$, then the samples were analyzed every $12 \mathrm{~h}$.

\subsection{Analytical methods}

Ma bamboo chip and steam exploded samples oven-dried and hand-kneaded, screened to 4060 mesh before the compositional analyses: ash (TAPPI T211 om-07), acid-insoluble lignin (TAPPI T222 om-06), cellulose and $\alpha$-cellulose (TAPPI T203 cm-09). Enzymatic hydrolysate and SSF samples were analyzed by high performance liquid chromatography (HPLC) using a ICSep ION-300 column and a R I detector for identifying organic acids, alcohols and mono sugars at $70{ }^{\circ} \mathrm{C}$; mobile phase was $0.0085 \mathrm{~N}$ sulfuric acid at flow rate $0.4 \mathrm{~mL} / \mathrm{min}$. Error bars indicates the standard deviations from triplicate experiments. 


\section{Results and discussion}

\subsection{Compositional analysis}

Various yields from pretreatment were obtained (on dried bamboo basis): $57 \%$ for acid steam explosion, $58 \%\left(200^{\circ} \mathrm{C}-10 \mathrm{~min}\right)$ to $83 \%\left(180^{\circ} \mathrm{C}-10 \mathrm{~min}\right)$ for acid steam explosion, $40 \%$ for kraft pulping and $39.8 \%$ for bleaching.

Table 1. Compositional analysis of Ma bamboo samples. Units are $\mathrm{mg} / \mathrm{g}$ dried wood.

\begin{tabular}{ccccc}
\hline Composition & ash & lignin & holocellulose & $\alpha$-cellulose \\
\hline $\begin{array}{c}\text { Raw Ma bamboo } \\
\text { Alkali steam-explosion }\end{array}$ & $17 \pm 4.36$ & $227.7 \pm 39.6$ & $722 \pm 66.4$ & $427.7 \pm 41.2$ \\
$180^{\circ} \mathrm{C}-10 \mathrm{~min}$ & $65 \pm 11$ & $160 \pm 14.1$ & $703 \pm 44$ & $480 \pm 20.5$ \\
$190^{\circ} \mathrm{C}-5 \mathrm{~min}$ & $54 \pm 13$ & $148 \pm 21.8$ & $820 \pm 81.7$ & $598 \pm 69.7$ \\
$190^{\circ} \mathrm{C}-10 \mathrm{~min}$ & $70 \pm 18.5$ & $175 \pm 31.9$ & $644 \pm 98.6$ & $473 \pm 117.4$ \\
$190^{\circ} \mathrm{C}-20 \mathrm{~min}$ & $46 \pm 8.1$ & $171 \pm 44.1$ & $702 \pm 35.2$ & $550 \pm 49.1$ \\
$200^{\circ} \mathrm{C}-10 \mathrm{~min}$ & $63 \pm 8.5$ & $180 \pm 29.8$ & $690 \pm 22.5$ & $525.5 \pm 44.1$ \\
Acidic steam-explosion ${ }^{*}$ & $7.6 \pm 0.5$ & $339 \pm 44.7$ & $526 \pm 82.9$ & $260 \pm 63.3$ \\
Kraft pulp $_{\text {Bleached pulp }}$ & $6.4 \pm 1.7$ & $25.5 \pm 3.6$ & $928 \pm 36.8$ & $847 \pm 41.2$ \\
\hline
\end{tabular}

* acid steam-exploded: $190^{\circ} \mathrm{C}$ held for 10 mins at $1.26 \mathrm{MPa}$

* alkali steam-exploded: $180^{\circ} \mathrm{C}$ to $200^{\circ} \mathrm{C}$ and $0.99 \mathrm{MPa}$ to $1.53 \mathrm{MPa}$ of 5 samples * N.D.: not detected.

Compositional analysis of raw material bamboo and pretreated samples were listed in Table 1. Great varieties of holocellulose contents were demonstrated for alkali steam exploded pulps. Generally, the lignin contents of alkali steam exploded pulps were lower then the ones of acidic steam exploded pulps. Holocellulose contents were highest for kraft pulp and bleached pulps. Acidic conditions might oxidize the cellulosic components and reduced the holocellulose of the pulps. In addition, the greater incomplete closure of compositional analysis for acidic steam exploded pulps, with its greater lignin content, was consistent to the above assumption. Lignin contents of alkali exploded pulps were increased with increasing treatment times. Although alkali would soften lignin in higher temperatures, soften lignin might melt onto cellulose fibrils; and lignin condensation [2] would contribute the increasing lignin contents among alkali steam exploded pulps.

\subsection{Enzyme hydrolysis}

Enzyme hydrolysis for pretreated samples was depicted in Fig.1. Enzyme loading was 9 IU endoglucanase $/ \mathrm{mL}, 0.89 \mathrm{IU}$ cellobiohydrolases $/ \mathrm{mL}$, and $7.1 \mathrm{IU}$ xylanase $/ \mathrm{mL}$ in reaction solutions. Conversions for sugar were based on dried weight of samples. $190^{\circ} \mathrm{C}-10 \mathrm{~min}$ was chosen for alkali steam-exploded bamboo in Figure 1. 


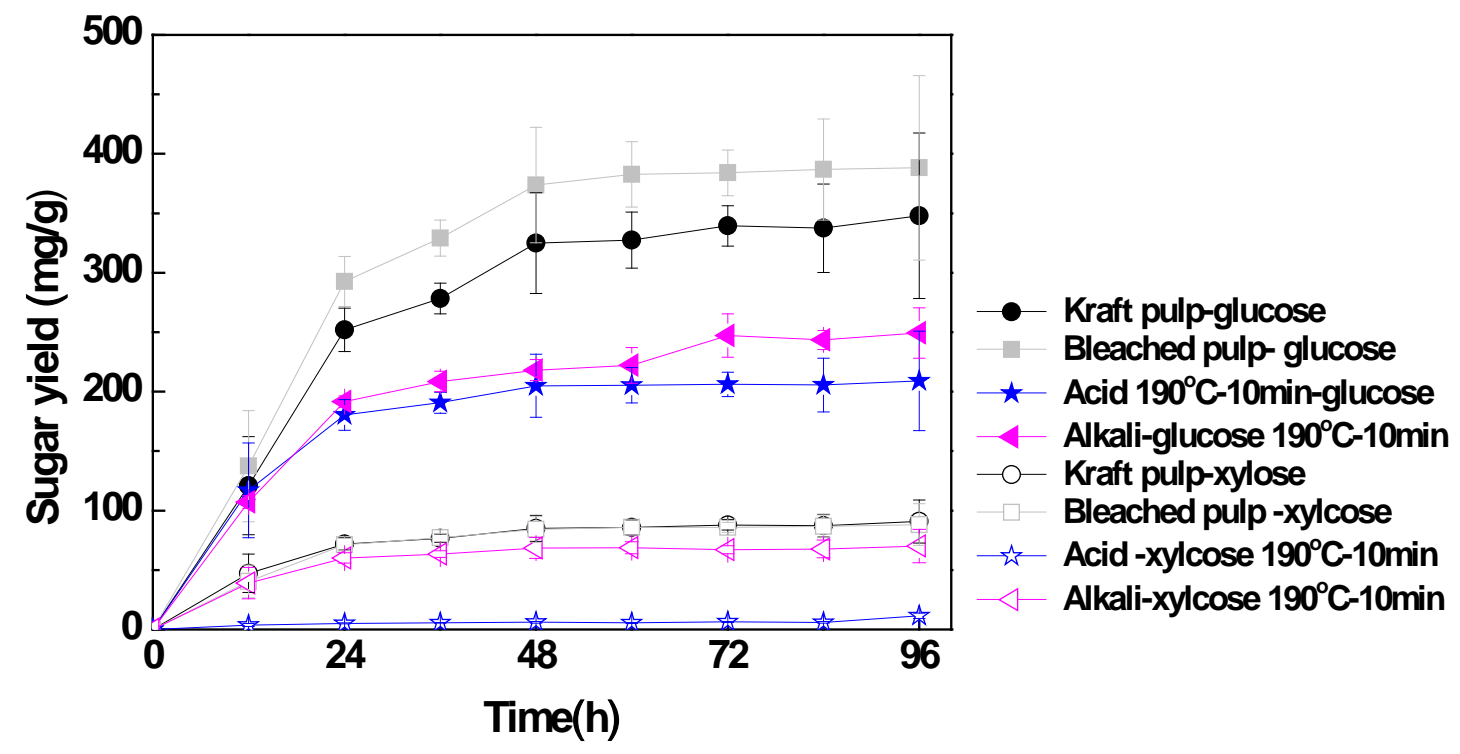

Figure 1. Enzyme hydrolysis to sugar conversion of pretreated bamboo samples with respect to time.

Glucose and xylose increased steadily prior to the first $24 \mathrm{~h}$ for all pulps, and the saturation was then reached at approx. 48 hours. At $96 \mathrm{~h}$, the bleached pulp showed a optimal y $388.2 \pm$ $69 \mathrm{mg} / \mathrm{g}$, kraft pulp $347.8 \pm 77 \mathrm{mg} / \mathrm{g}$, alkali steam-exploded $\left(190^{\circ} \mathrm{C}-10 \mathrm{~min}\right) 249.3 \pm 21 \mathrm{mg} / \mathrm{g}$ and acid steam-exploded $209.1 \pm 41 \mathrm{mg} / \mathrm{g}$.

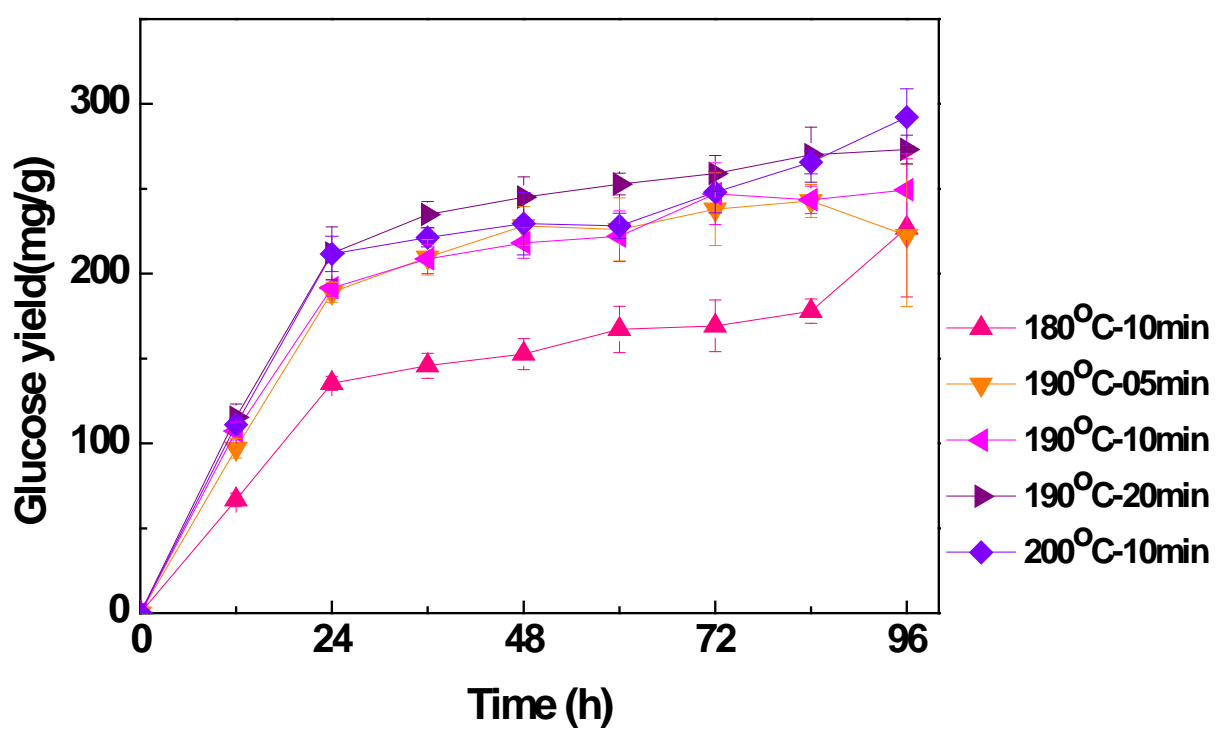

Figure 2. Enzyme hydrolysis to sugar conversion of alkali steam-exploded bamboo samples with respect to time.

Fig. 2 showed hydrolysis for 5 alkali steam-exploded samples, with other conditions as same as Figure 1. Except for the pulp for $180^{\circ} \mathrm{C}-10 \mathrm{~min}$, the other pulps have similar glucose yields at around $250 \mathrm{mg}$ glucose per gram dried bamboo. Interestingly, the yields of $200^{\circ} \mathrm{C}-10 \mathrm{~min}$ pulp were still slightly growing after 48 hours. 


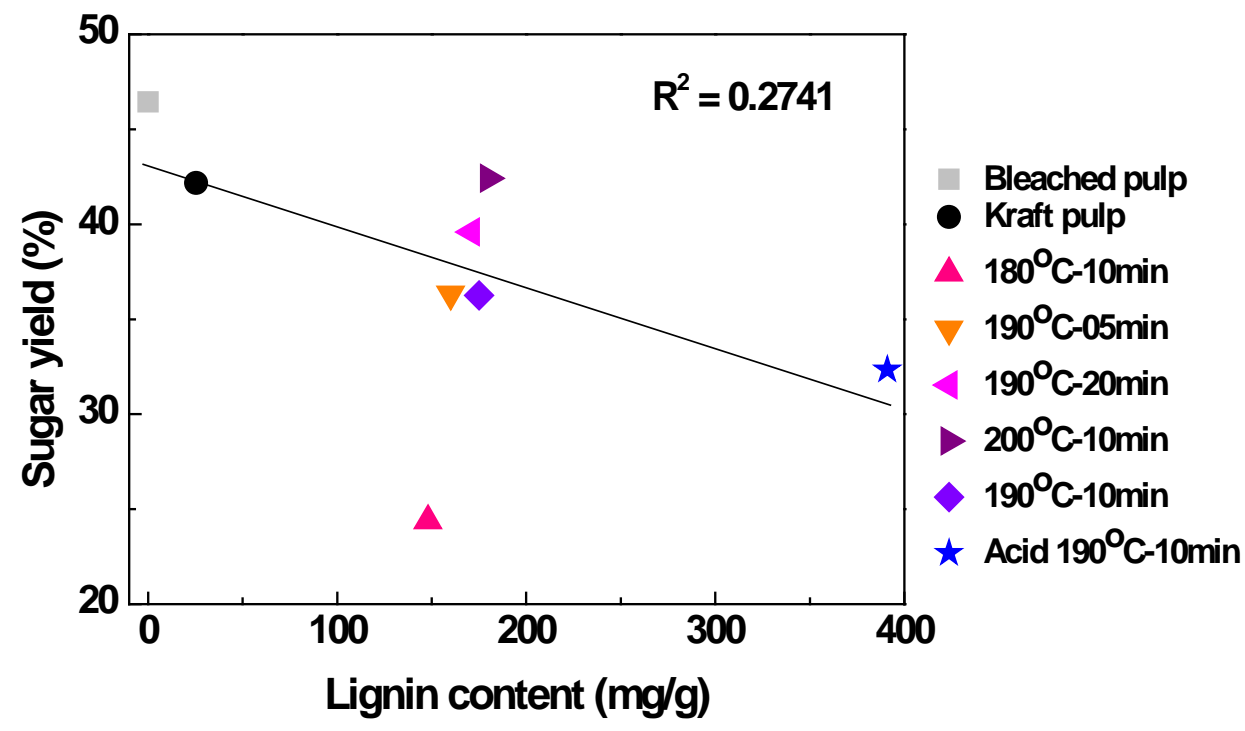

Figure 3. Correlation between pulp lignin contents and sugar yield during enzyme hydrolysis.

Effects of lignin contents on sugar yield during enzyme hydrolysis were shown by Figure 3 . The trend was clearly shown, although the correlation was not clear. If the $180^{\circ} \mathrm{C}-10 \mathrm{~min}$ pulp were removed, the correlation would be more obvious. There was almost no correlation for lignin contents and sugar yield among all alkali steam-exploded samples. The lowest sugar yield of $180^{\circ} \mathrm{C}-10 \mathrm{~min}$ pulp suggested that other factors, like fiber dimensions, might also play important roles during enzyme hydrolysis. Since the mechanical separation of $180^{\circ} \mathrm{C}-10 \mathrm{~min}$ pulp during alkali steam explosion should be the least.

\subsection{Simultaneous saccharification and fermentation (SSF)}

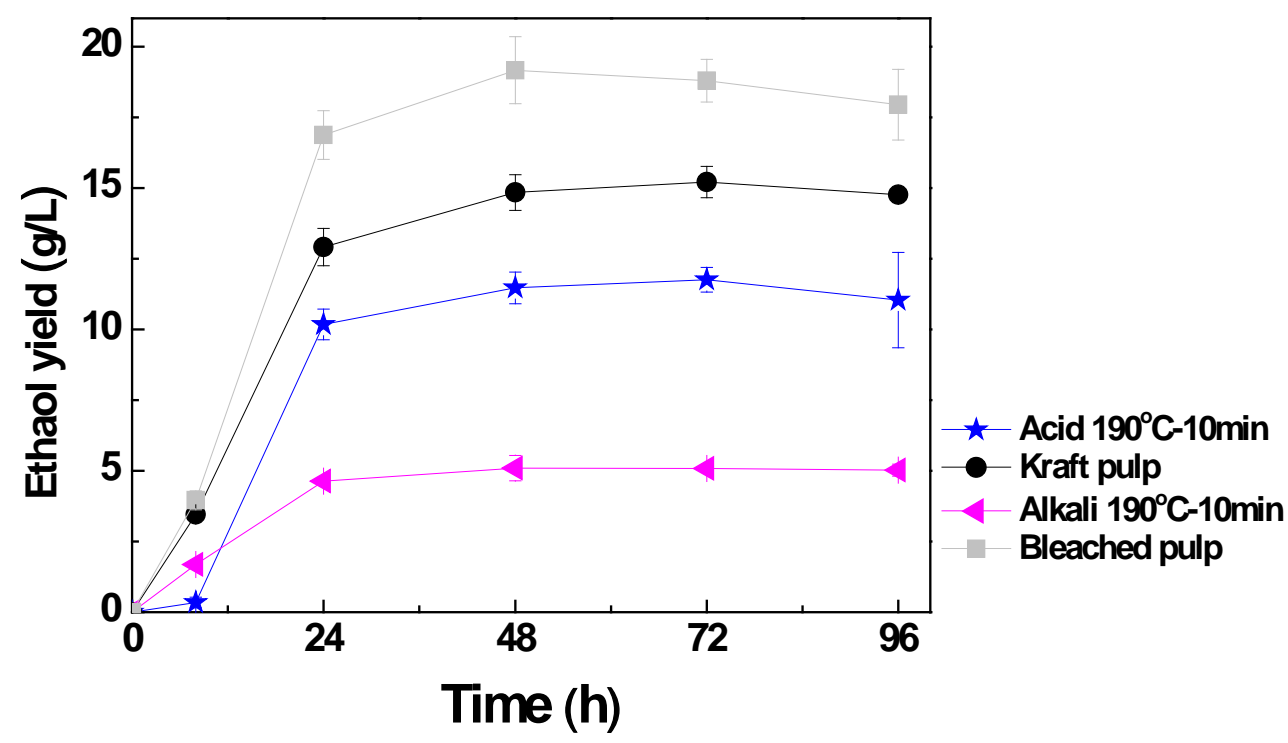

Figure 4. Ethanol yields for acid, alkali $\left(190^{\circ} \mathrm{C}-10 \mathrm{~min}\right)$ steam-exploded pulp, kraft and bleached pulps by SSF. 
Ethanol yields for acid, alkali steam-exploded pulp, kraft and bleached pulps by SSF were shown by Figure 4 . As expected, the ethanol yields of bleached and kraft pulps were higher than the values of acid and alkaline $\left(190^{\circ} \mathrm{C}-10 \mathrm{~min}\right)$ steam exploded pulps. Although the lignin content of alkaline $190^{\circ} \mathrm{C}-10 \mathrm{~min}$ pulp was lower than the value of acid steam exploded pulps, melted lignin in alkali conditions might further hamper enzyme hydrolysis and fermentation.

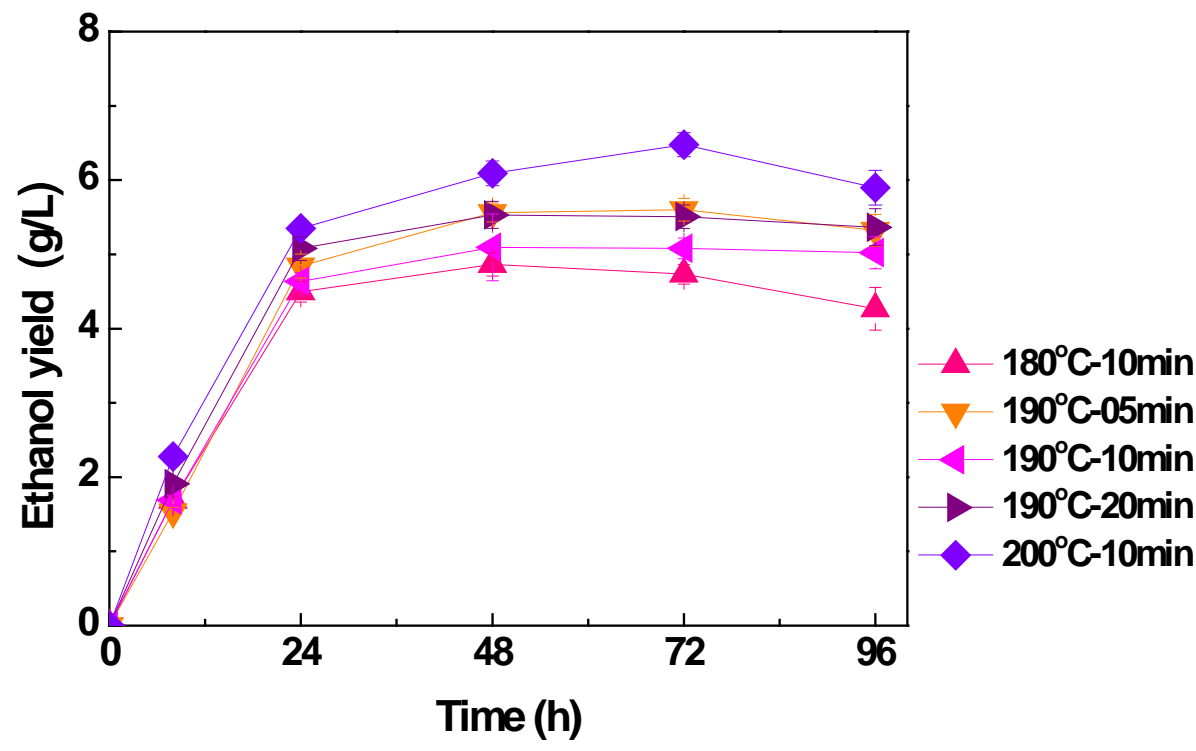

Figure 5. Ethanol yields for five alkali steam-exploded pulps by SSF.

Ethanol yields for five alkali steam-exploded pulps by SSF were shown by Figure 5 . The yields increased steadily for the first 24 hours; then the optimal yields were reached after the next 48 hours. The yield from $200{ }^{\circ} \mathrm{C}-10 \mathrm{~min}$ pulp was the most, and the yield from $180{ }^{\circ} \mathrm{C}$ $10 \mathrm{~min}$ pulp was the least. With the respect of results from Table 1, lignin contents were not the deciding factor for the above observation.

\subsection{Estimated of ethanol yields from bamboo in Taiwan}

The bamboo covers 152,300 ha, with overall volume of $535,000 \mathrm{~m}^{3}$ in Taiwan [1]. Its mass growth were estimated at $10 \sim 25 \%$. Assuming $160,000 \mathrm{~m}^{3}$ (80,000 ton) of bamboo were harvested annually, Table 2 lists annual ethanol production from bamboo estimated by SSF following different pretreatments.

Table 2. Annual ethanol production from bamboo estimated by SSF following different pretreatments.

\begin{tabular}{ccccc}
\hline & $\begin{array}{c}\text { Pretreatment } \\
\text { yield }(\%)\end{array}$ & $\begin{array}{c}\text { Ethanol yield } \\
(\mathrm{g} \text { EtOH / g pulp })\end{array}$ & $\begin{array}{c}\text { Raw material to ethanol } \\
(\%)\end{array}$ & $\begin{array}{c}\text { Estimate yield } \\
\left(10^{4} \text { tons/Yr }\right)\end{array}$ \\
\hline Acid & 57 & 0.23 & 13.40 & 1.07 \\
$180^{\circ} \mathrm{C}-10 \mathrm{~min}$ & 83 & 0.10 & 8.07 & 0.64 \\
$190^{\circ} \mathrm{C}-05 \mathrm{~min}$ & 80 & 0.11 & 8.96 & 0.72 \\
$190^{\circ} \mathrm{C}-10 \mathrm{~min}$ & 76 & 0.10 & 7.73 & 0.61 \\
$190^{\circ} \mathrm{C}-20 \mathrm{~min}$ & 63 & 0.11 & 6.97 & 0.55 \\
$200^{\circ} \mathrm{C}-10 \mathrm{~min}$ & 58 & 0.13 & 7.51 & 0.60 \\
Kraft pulp & 40 & 0.30 & 12.16 & 0.97 \\
Bleached pulp & 39.8 & 0.38 & 15.25 & 1.22 \\
\hline
\end{tabular}




\subsection{Energy balance estimation}

Energy balance estimation for bamboo ethanol, expressed by MJ per liter ethanol, were listed in Table 3. Energy consumption analyses for production of fuel ethanol from lignocellulosic biomass [6] and pulp/paper processing [7] were followed by this study. Table 3 showed that the net energy gains could be achieved for the processes with greater ethanol yields: acid steam explosion and fully bleached pulps. But net energy gains must include the utilization for combustion of the fermented waste, lignin.

Table 3. Energy balance estimation for bamboo ethanol (MJ per liter ethanol produced)

\begin{tabular}{ccccccccc}
\hline \multirow{2}{*}{ Process } & \multicolumn{4}{c}{ Energy Input } & \multicolumn{3}{c}{ Energy Output } & Net \\
\cline { 2 - 9 } & $\begin{array}{c}\text { Stock } \\
\text { preparation }\end{array}$ & Pretreatment & SSF & $\begin{array}{c}\text { Distillation, } \\
\text { dehydration, } \\
\text { purification }\end{array}$ & Total input & $\begin{array}{c}\text { Lignin } \\
\text { power }\end{array}$ & Ethanol & $\begin{array}{c}\text { Energy } \\
\text { gain }\end{array}$ \\
\hline Acid explo. & 2.483 & 35.16 & 13.93 & 13.7 & 65.27 & 48.7 & 21.2 & 4.62 \\
$180^{\circ} \mathrm{C}-10$ min & 4.124 & 60.84 & 15.62 & 28 & 108.6 & 60.9 & 21.2 & -26.49 \\
$190^{\circ} \mathrm{C}-05$ min & 3.714 & 52.80 & 15.43 & 27.4 & 99.54 & 60.1 & 21.2 & -17.33 \\
Bleached pulp & 2.182 & 34.64 & 11.73 & 11 & 59.55 & 40.6 & 21.2 & 2.24 \\
\hline
\end{tabular}

\section{Conclusions}

Biomass derived by photosynthesis has strong potentials from bioethanol production. The present study demonstrated bamboo in Taiwan was a source couldn't be ignored for bioethanol production. Bamboos are some of the fastest growing plants in the world. Planned harvesting for will maximize its carbon sequestration potential without ecological damage. As much as 10,700 tons of bioethanols could be produced annually by acidic steam explosion.

\section{References}

[1] Taiwan Forestry Bureau, The Third Survey of Forest Resources and Land Use in Taiwan, Forestry Bureau of Council of Agriculture Executive Yuan, Taiwan, R.O.C., 1995.

[2] F. Kobayashi, H. Take, C. Asada and Y. Nakamura, Methane production from steamexploded bamboo. Journal of bioscience and bioengineering 97(6), 2004, pp. 426-428.

[3] M. Takagi, S. Abe, S. Suzuki, G.H. Emert and N. Yata, A method for production of alcohol directly from cellulose using cellulase and yeast, In: Ghose, T.K. (Ed.), Proceedings of Bioconversion of cellulosic substances into energy, chemicals and microbial protein. I.I.T., New Delhi, 1977, pp. 551-571.

[4] C. Wyman and N. Hinman, Ethanol: fundamentals of production from renewable feedstocks and use as a transportation fuel. Applied Biochemistry and Biotechnology 2425, 1988, pp735-742.

[5] CH Ko, ZP Lin, J Tu, CH Tsai, CC Liu, HT Chen, TP Wang, Xylanase production by Paenibacillus campinasensis BL11 and its pretreatment of hardwood kraft pulp bleaching, Int Biodeterior Biodegrad 64, 2010, pp13-19.

[6] C. A. Cardona and T. Sanchez, Energy consumption analysis of integrated flowsheets for production of fuel ethanol from lignocellulosic biomass. Energy 31(13), 2006, pp 24472459.

[7] M. Ruth, Jr T. Harrington, Dynamics of material and energy use in US pulp and paper manufacturing, Journal of Industrial Ecology 1(3), 1997, pp147-168. 